\title{
PERTUMBUHAN ASURANSI SYARIAH DI DUNIA DAN INDONESIA
}

\author{
Muhammad Maksum*
}

\begin{abstract}
The Growth of Islamic Insurance in the World and Indonesia. The movement of Islamic insurance growth as one of an Islamic finance instruments is not as fast as the growth of Islamic banking. Nevertheless, it shows a significance growth wether in the world or Indonesia. In the debate over the legal status of insurance, the insurance based on mutual help and free of ribâ can be an alternative for those who want a lawful economic transactions. The increasing public appreaciation of the Islamic economic system allows the growth of Islamic insurance in the future rapidly.
\end{abstract}

Keywords: islamic insurance, conventional insurance, gharâr, jahâlah, transactions

\begin{abstract}
Abstrak: Pertumbuhan Asuransi Syariah di Dunia dan Indonesia. Geliat pertumbuhan asuransi syariah sebagai salah satu instrumen keuangan syariah tidak secepat pertumbuhan perbankan syariah. Walaupun demikian, pertumbuhan industri asuransi syariah baik di Indonesia maupun di dunia menunjukkan peningkatan yang signifikan. Di tengah perdebatan status hukum asuransi, asuransi berbasis tolong-menolong dan bebas riba menjadi alternatif bagi mereka yang menghendaki transaksi ekonomi yang halal. Semakin meningkatnya apresiasi masyarakat terhadap sistem ekonomi berbasis syariah ini, memungkinkan pertumbuhan asuransi syariah lebih cepat di masa yang akan datang.
\end{abstract}

Kata Kunci: asuransi syariah, asuransi konvensional, gharâr, jahâlah, akad

Naskah diterima: 5 Juni 2010, direvisi: 2 Oktober 2010, disetujui: 13 Oktober 2010.

* STAI Al-Hikmah Jakarta. Jl Jeruk Purut 10 RT 001/02, Cilandak Timur, Pasar Minggu Kota Jakarta Kode Pos 12560. E-mail: maksum.2010@gmail.com 


\section{Pendahuluan}

Asuransi atau assurantie (Belanda) atau insurance (Inggris) ${ }^{1}$ mengandung arti menanggung suatu kerugian yang terjadi. Sementara dalam bahasa Arab, asuransi terambil dari kata أمن, yang berarti aman, yaitu berkenaan dengan ketenangan jiwa dan meniadakan rasa takut. ${ }^{2}$ Muhammad Sayyid al-Dasûkî mengartikan asuransi sebagai transaksi yang mewajibkan kepada pihak tertanggung untuk menunaikan kewajiban-kewajibannya berupa jumlah uang kepada pihak penanggung, dan akan menggantikannya manakala terjadi peristiwa kerugian yang menimpa si tertanggung. ${ }^{3}$

Sedangkan di Indonesia, menurut Undang-Undang No. 1 Tahun 1992, asuransi diartikan sebagai perjanjian antara dua pihak atau lebih, di mana pihak penanggung mengikatkan diri kepada tertanggung, dengan menerima premi asuransi untuk memberikan penggantian kepada tertanggung karena kerugian, kerusakan atau kehilangan keuntungan yang diharapkan, atau tanggung jawab hukum kepada pihak ketiga yang mungkin akan diderita tertanggung yang timbul dari suatu peristiwa yang tidak pasti, atau untuk memberikan suatu pembayaran yang didasarkan atas meninggal atau hidupnya seseorang yang dipertanggungkan. ${ }^{4}$

Sementara menurut DSN bahwa yang dimaksud dengan asuransi syariah (ta'mîn, takâful atau tadhâmun) adalah usaha saling melindungi dan tolongmenolong di antara sejumlah orang/pihak melalui investasi dalam bentuk aset dan/atau tabarru' yang memberikan pola pengembalian untuk menghadapi risiko tertentu melalui akad (perikatan) yang sesuai dengan syariah. ${ }^{5}$

Pada mulanya, asuransi didirikan sebagai upaya untuk saling melindungi dan menolong di antara para pihak dalam rangka menghadapi kemungkinan yang akan terjadi yang tidak mungkin dapat ditanggung sendiri. Kemungkinan terburuk dapat saja terjadi, dan karena itu perlu mempersiapkan diri untuk menghadapinya. Persiapan itu dapat dilakukan oleh diri sendiri atau berkelompok dalam bentuk asuransi atau perkongsian untuk saling menanggung.

Kini asuransi lebih dekat pada nilai bisnisnya. Sebagai perusahaan, baik asuransi konvensional maupun asuransi syariah, sama-sama merupakan lemba-

\footnotetext{
${ }^{1}$ Lihat Oxford Learner's Pocket Dictionary, New Edition.

${ }^{2}$ Abû al-Fadhl Jamâl al-Dîn Muhammad Ibn Makram Ibn Manzhûr, Lisân al-'Arab, (Lubnân: Dâr Shâdir Bayrût, t.th.), h. 110.

${ }^{3}$ Muhammad Sayyid al-Dasûkî, al-Ta'mîn wa Mauqif al-Syarî'ah al-Islâmiyyah Minhu, (Kairo: Direktorat Tinggi Urusan Agama Mesir, 1967), h. 16.

${ }^{4}$ Undang-undang Republik Indonesia Nomor 2 Tahun 1992 Tentang Usaha Perasuransian.

${ }^{5}$ DSN-MUI dan Bank Indonesia, Himpunan Fatwa Dewan Syariah Nasional MUI, Edisi Revisi 2006 (Jakarta: DSN-MUI, 2006), h. 127.
} 
ga bisnis, yang artinya memiliki tujuan yang sama yaitu mencari keuntungan. Keduanya, dengan pelbagai cara dan metode, berupaya mencari sebanyak-banyaknya orang agar menjadi nasabah mereka.

Dari pengertian di atas, sebenarnya perbedaan utama dari asuransi syariah dan konvensional terletak pada tujuan dan landasan operasional. Dari sisi tujuan, asuransi syariah bertujuan saling menolong (ta'âwunî) sedangkan dalam asuransi konvensional tujuannya penggantian (tabâdulî). Dari aspek landasan operasional, asuransi konvensional melandaskan pada peraturan perundangan, sementara asuransi syariah melandaskan pada peraturan perundangan dan ketentuan syariah.

Dari kedua perbedaan ini muncul perbedaan lainnya, mengenai hubungan perusahaan dan nasabah, keuntungan, memperhatikan larangan syariah, dan pengawasan. Berkaitan dengan hubungan perusahaan-nasabah, ini terkait dengan masalah kontrak (akad), di mana dalam asuransi syariah perusahaan adalah pemegang amanah (wakîl), sementara dalam asuransi konvensional perusahaan adalah pemilik dana asuransi. Karena itu, keuntungan asuransi syariah adalah sebagiannya milik nasabah, sedangkan keuntungan asuransi konvensional seluruhnya menjadi milik perusahaan.

Dalam hal ketentuan syariah, asuransi syariah dibatasi dalam kegiatannya oleh larangan-larangan syariah, di antaranya larangan mempraktikkan riba dalam bentuk apapun, menghindarkan praktik perjudian, ketidakpastian, dan ketidakjelasan (maysir, gharar, jahâlah), dan berinvestasi dalam bidang yang halal. Selain itu, dalam konteks Indonesia, asuransi syariah wajib memiliki dewan pengawas syariah yang bertugas mengawasi kesesuaian praktik perusahaan asuransi dengan ketentuan syariah. ${ }^{6}$

Namun demikian, ulama berbeda pendapat mengenai status hukum dari asuransi, baik asuransi syariah maupun asuransi konvensional. Berikut dipaparkan perbedaan pendapat ulama tentang hukum dari asuransi. Pertama, asuransi konvensional. Ulama menanggapi berbeda mengenai status hukum dari kegiatan asuransi konvensional, ada yang membolehkan dan ada yang melarang. Adapun ulama yang membolehkan ${ }^{7}$ di antaranya: Syaykh 'Abd al-Rahmân 'Isâ dan Syaykh Muhammad al-Bâhî, guru besar Universitas Al-Azhar, Syaykh Muhammad Yûsuf, guru besar Universitas Kairo, Syaykh 'Abd al-Wahhâb Khallâf, guru besar hukum Islam Universitas Kairo, Bahjah Hilmî, penasihat Pengadilan Tinggi Mesir, Syaykh

${ }^{6}$ Ahmad Sâlim Milhim, al-Ta'mîn al-Islâmî, (Oman: Dâr al-A'lâm, 2002), Cet. I, h. 115-117; juga Syakir Sula, Asuransi Syariah, Konsep dan Sistem Operasional, (Jakarta, Gema Insani, 2004), Cet. I, h. 293-319.

${ }^{7}$ Syakir Sula, Asuransi Syariah, Konsep dan Sistem Operasional, h. 71-76. 
Muhammad Dasûkî, Syaykh Muhammad Najâtullâh Shiddîqî, dosen Universitas King Abdul Aziz, Syaykh Muhammad Ahmad, pakar ekonomi dari Pakistan, Syaykh Muhammad al-Madhânî, dan Syaykh Musthafâ Ahmad al-Zarqâ, guru besar Universitas Syiria.

Para ulama di atas umumnya beranggapan bahwa asuransi adalah kreasi praktik baru, yang sebelumnya tidak ditemukan dengan tujuan untuk saling tolong-menolong. Asuransi merupakan bentuk perkongsian (koperasi) yang dibenarkan dalam Islam, selama tidak mempraktikkan riba. Bahkan, Syaykh Muhammad al-Bâhî, dalam bukunya, Nizhâm al-Ta `mîn fî Hâdzihi Ahkâm alIslâm wa Dharûrat al-Mujtama' al-Mu'âshir, beralasan tentang kehalalan asuransi sebagai berikut: Pertama, asuransi merupakan suatu usaha yang bersifat tolongmenolong. Kedua, asuransi mirip dengan akad mudhârabah dan untuk mengembangkan harta benda. Ketiga, asuransi tidak mengandung unsur riba. Keempat, asuransi tidak mengandung tipu daya. Kelima, asuransi tidak mengurangi tawakal kepada Allah Swt. Keenam, asuransi suatu usaha untuk menjamin anggotanya yang jatuh melarat karena suatu musibah. Ketujuh, asuransi memperluas lapangan kerja.

Kehalalan asuransi, menurut Syaykh Muhammad Dasûkî, didasarkan atas pertimbangan agama pula. Menurutnya, kehalalan itu dikarenakan beberapa sebab. Pertama, asuransi sama dengan syirkah mudhârabah; Kedua, asuransi sama dengan akad kafâlah atau syirkah `inan; Ketiga, pelaksanaan asuransi dapat didasarkan atas firman Allah dalam surah al-An'âm [6]: 82 yang menjelaskan bahwa orang-orang yang beriman dan tidak mencampuradukkan iman mereka dengan kezaliman (syirik), mereka itulah yang mendapat keamanan dan mereka itu adalah orang-orang yang mendapat petunjuk.

Selain ada yang menghalalkan, umumnya ulama mengharamkan asuransi konvensional. Ulama fikih yang dianggap pertama kali membahas dan mengharamkan asuransi adalah Ibn al-'Abidîn (1784-1836), dari kalangan Hanafiyyah, dalam kitabnya Hâsyiyah Ibn al-'Abidîn ( Mukhtâr Syarh Tanwîr al-Abshâr). Menurutnya kegiatan asuransi hukumnya haram karena alasan mewajibkan sesuatu yang tidak wajib, iltizâm mâ lam yalzam.

Ia mencontohkan seorang pedagang yang hendak mengirim barang menyewa kapal dari seorang Harbî. Pedagang itu harus membayar biaya pengiriman dan biaya jaminan sukarah, semacam premi asuransi. Dengan membayar premi ini, jika nanti ada kerusakan atau tenggelam, maka Harbî akan membayar atau mengganti barang pedagang itu. Praktik semacam ini, menurut Ibn al-'Âbidîn, dilarang. Haram hukumnya pedagang mengambil uang pengganti dari barang- 
barangnya yang musnah. ${ }^{8}$

Ulama lain yang melarang adalah Syaykh Muhammad Bakhit al-Muthî‘̂̂ (1854-1935), seorang mufti Mesir. Menurut dia, asuransi adakalanya menggunakan akad kafâlah atau ta'addî/itlâf. Pada akad kafâlah, pertanggungan akan diganti barang yang hilang/rusak atau seharganya. Sementara dalam asuransi tidak terjadi semacam itu. Pendapat ini didasarkan pada firman Allah dalam Q.s. Yûsuf [12]: 72:

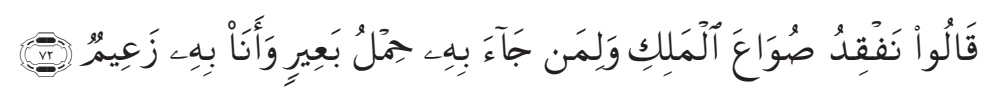

Penyeru-penyeru itu berkata, "Kami kehilangan piala raja, dan siapa yang dapat mengembalikannya akan memperoleh bahan makanan (seberat) beban unta, dan aku menjamin terhadapnya". (Q.s. Yûsuf [12]: 72)

Syaykh Muhammad al-Ghazâlî memerinci sebab-sebab keharaman dari asuransi konvensional. Pertama, apabila waktu perjanjian telah habis, maka uang premi dikembalikan kepada terjamin dengan disertai bunganya dan ini riba. Apabila jangka waktu yang tersebut di dalam polis belum habis dan perjanjian diputuskan, maka uang premi dikembalikan dengan dikurangi biayabiaya administrasi. Muamalah semacam ini tidak sesuai dengan syariat Islam. Kedua, ganti kerugian yang diberikan kepada terjamin pada waktu terjadinya peristiwa yang disebutkan dalam polis, tidak dibenarkan Islam. Karena, orangorang yang mengerjakan asuransi bukan syarikat di dalam untung dan rugi, sedangkan orang-orang lain ikut memberikan sahamnya dalam uang yang diberikan kepada terjamin. Ketiga, asuransi menjalankan usahanya dengan sistem riba. Keempat, perusahaan asuransi menjalankan kinerjanya dengan sistem lotre, hanya sedikit pihak yang mendapat manfaat. Kelima, kegiatan asuransi merupakan kegiatan yang mengarahkan pada dosa.

Ulama-ulama lain, seperti Muhammad Yûsuf Qaradhawî, Syaykh Abû Zahrah, Muhammad Muslehuddin, Syaykh Wahbah al-Zuhailî, Husain Hâmid, mengharamkan asuransi karena adanya praktik riba, gharar, dan perjudian. Begitu juga dengan ulama Indonesia seperti Ali Yafie, mengharamkannya karena tidak sesuai dengan prinsip-prinsip syariah. ${ }^{9}$

Kemudian perhimpunan ulama fikih (Majma' al-Fiqh al-Islâmî), pada kongresnya tanggal 10 Sya'ban tahun $1398 \mathrm{H}$ telah bersepakat mengharamkan

${ }^{8}$ Ahmad Sâlim Milhim, al-Ta'mîn al-Islâmî, h. 43-44.

${ }^{9}$ Syakir Sula, Asuransi Syariah, Konsep dan Sistem Operasional, h. 58-70 
asuransi konvensional dengan alasan: Pertama, asuransi mengandung gharar; Kedua, asuransi mempraktikkan riba; Ketiga, mengandung permainan lotre; Keempat, mengakibatkan memakan harta orang lain secara tidak sah. ${ }^{10}$

Kedua, asuransi syariah. Ulama dan umat Islam sepakat atas kehalalan asuransi syariah. Pendapat ini didasarkan atas kesepakatan Muktamar Ulama Muslim Ke-II pada tahun 1960, Muktamar Ulama Muslim Ke-VII tahun 1392 H, dan Pertemuan Ulama Fikih tahun $1938 \mathrm{H}$.

Kehalalan asuransi didasarkan pada pertimbangan praktiknya menjauhkan dari sistem riba, gharar, jahâlah, dan qimâr. Asuransi syariah menggunakan sistem persekutuan dan pertolongan (syirkah wa ta'âwuniyyah). Praktik ini dibenarkan menurut agama, bahkan didorong untuk saling menolong dalam takwa dan kebaikan. ${ }^{11}$

\section{Perkembangan di Dunia}

Asuransi yang pertama kali didirikan adalah asuransi takâful di Sudan pada tahun 1979, yang dikelola oleh Dâr al-Mâl al-Islâmî Group. Dâr al-Mâl melebarkan sayap bisnisnya ke negara-negara Eropa dan Asia lainnya. Setidaknya ada empat asuransi takâful dan re-takâful pada tahun 1983, yang berpusat di Geneva, Bahamas, Luxembourg, dan Inggris.

Padahal secara legalitas keislaman, sistem asuransi syariah baru diakui dan diadopsi oleh ulama dunia pada tahun 1985. Pada tahun tersebut, Majma alFiqh al-Islâmî mengadopsi dan mengesahkan takâful sebagai sistem asuransi yang sesuai dengan syariah. Artinya, perkembangan takâful lebih didasarkan atas kreasi dan kebutuhan umat muslim, ketimbang didorong oleh fatwa. Sistem asuransi diadopsi sebagai sistem saling menolong dan membantu di antara para pesertanya. $^{12}$

Hingga saat ini, tidak kurang dari 65 perusahaan asuransi syariah tersebar di seluruh dunia. Perkembangan asuransi dibilang cukup pesat. Dari asset $\$ 550$ juta pada tahun 2000, $\$ 193$ juta diantaranya berada di Asia Pasifik, meningkat menjadi $\$ 1,7$ milyar. Angka ini terus meningkat seiring dengan peningkatan jumlah asuransi syariah di dunia. Pada tahun 2004 asetnya sudah mencapai \$2 milyar.

Angka-angka di atas merupakan kumulasi untuk asuransi jiwa dan selain jiwa. Asuransi keluarga syariah mendominasi perkembangan asuransi dunia,

\footnotetext{
${ }^{10} \mathrm{~A}$ hmad Sâlim Milhim, al-Ta'mîn al-Islâmî, h. 45-47.

${ }^{11}$ Ahmad Sâlim Milhim, al-Ta'mîn al-Islâmî, h. 65-70.

${ }^{12}$ Salahuddin Ahmed, Islamic Banking, Finance, and Insurance; a Global Overview, (Kuala Lumpur; A.S. Noordeen, 2006), h. 516.
} 
mencapai 75\%, dimana 60\%-nya berasal dari asuransi jiwa syariah.

Untuk merespons dan memajukan industri asuransi syariah, Malaysia mendirikan Lembaga Penelitian dan Pelatihan Bank Syariah (BIRTI), yang concern pada bidang pendidikan dan pengembangan sumber daya manusia. Lembaga ini telah memberi andil dalam pengembangan industri syariah di belahan Asia. Dengan dukungan BIRTI, Takâful Malaysia menjalin kerjasama dengan Sri Lanka, Arab Saudi, dan pernah pula memberikan dukungan teknis (technical assistance) untuk operasionalisasi takâful Australia. Selain itu dukungan teknis dilakukan di negara Lebanon, Bangladesh, dan Algeria. Kemudian pada tahun 1997, didirikan lagi The Asean Re-takâful International Labuan Ltd (ARILL).

Perkembangan asuransi syariah yang cukup progresif terjadi di negaranegara Arab, terutama negara Arab Saudi, Qatar, Kuwait, dan Bahrain. Negara ini pertama kali mendirikan Asuransi Takâful Internasional pada tahun 1989. Pangsa pasar asuransi di Bahrain diperkirakan mencapai 65 juta dinar (\$172 juta). Produk yang diluncurkan oleh asuransi Bahrain ini antara lain, Asuransi Haji dan Umrah yang diperkenalkan pada Januari 2004, asuransi kesehatan (The Best Doctors Takâful Health Care) diluncurkan pada September 2004, dan takâful pendidikan. Ketiga produk ini mendominasi dibanding produk lainnya. ${ }^{13}$

Beberapa industri asuransi syariah yang berkembang di Arab Saudi antara lain: Islamic Arab Insurance Company (al-Baraka Group) (1980), Islamic Corporation for the Insurance, Investment dan Export Credit (1995), Islamic Insurance Company Ltd., Islamic Insurance and Reinsurance Company (1985), Al-Aman coOperative Insurance (AlRajhi) (1985), Global Islamic Insurance co. (1986), Islamic Takafaul and Re-takâful Company (DMI Group) (1986), dan lain sebagainya.

Di belahan benua Afrika, asuransi syariah pertama kali didirikan di Ghana, tahun 1994, yaitu Metropolitan Insurance Company Limited (MIT). MIT merupakan satu-satunya asuransi yang beroperasi secara syariah di Ghana, dengan menerapkan sistem mudhârabah dan takâfulî.

Selaian Ghana, di Nigeria, African Alliance Insurance Company Limited, mendirikan Islamic Life Insurance System (Takâful) pada oktober 2003. Di Senegal didirikan Islamic Takâful and Retakâful Co. dan Sonar AlAmane (AlBaraka Group). Juga Takâful Trinidad and Tobago Friendly Society didirikan di Trinidad dan Tobago pada tahun 1999.

Sementara di Eropa, negara Inggris merupakan pelopor pengembangan asuransi syariah. Melalui HSBS's Amanah, Inggris bercita-cita menjadi leading sector bagi pengembangan asuransi syariah di Eropa dan negara lainnya. Di

\footnotetext{
${ }^{13}$ Salahuddin Ahmed, Islamic Banking, Finance, and Insurance, h. 518-519.
} 
negara ini dirikan pula International Cooperative and Mutual Insurance Federation (ICMIF), yang menghimpun 150 orang dari 82 anggota organisasi dari 52 negara di dunia. Lembaga ini bertujuan untuk memajukan dan memperkenalkan sistem asuransi syariah ke pelbagai negara. ${ }^{14}$

Di Amerika, asuransi syariah pertama kali berdiri pada Desember 1996. Takâful USA Insurance Company, asuransi pertama di Amerika, didirikan untuk menampung sedikitnya 12 juta penduduk Muslim di negara Paman Sam itu. Demikian pula di Australia telah berdiri Australia Takâful Assosiation Inc.

Malaysia dan Bank Pembangunan Islam (IDB) telah menandatangani kontrak kerjasama untuk memajukan industri asuransi syariah ini di negaranegara Muslim, terutama di negara-negara anggota OKI.

Perkembangan asuransi syariah ini menunjukkan respons yang positif dari masyarakat dunia akan sistem asuransi berbasis syariah. Hal ini menunjukkan bahwa asuransi syariah dapat diterima dan menjadi alternatif bagi sistem asuransi yang berjalan selama ini.

Berikut data perusahaan asuransi yang ada di dunia: ${ }^{15}$

\begin{tabular}{|c|c|c|c|}
\hline Benua/Negara & Perusahaan Asuransi & Benua/Negara & Perusahaan Asuransi \\
\hline Asian Countries & & Middle-East & \\
\hline Indonesia & $\begin{array}{l}\text { - PT. Asuransi Takâful } \\
\text { Keluarga (1994) } \\
\text { - PT. Asuransi Takâful } \\
\text { Umum (1995) }\end{array}$ & Bahrain & $\begin{array}{ll}\text { - } & \text { Al-Salam Islamic } \\
& \text { Takâful (1992) } \\
\text { - } & \text { Bahrain Islamic } \\
& \text { Insurance } \\
\text { - } & \text { Islamic Insce \& Re- } \\
& \text { ince (1985) } \\
\text { - } & \text { Sarikat Takâful Al- } \\
& \text { Islamiyah (1983) } \\
\text { - } & \text { Takâful International } \\
& (1989)\end{array}$ \\
\hline Malaysia & $\begin{array}{l}\text { - Syarikat Takâful } \\
\text { Malaysia (1984) } \\
\text { - } \text { Takâful Nasional } \\
\text { (1993) } \\
\text { - } \text { Mayban Takâful } \\
\quad \text { (2002) } \\
\text { - Takâful Ikhlas } \\
\text { (2003) } \\
\text { - Takâful aril Labuan } \\
\text { (1999) }\end{array}$ & Jordan & $\begin{array}{l}\text { Islamic Insurance Co. } \\
\text { Plc }\end{array}$ \\
\hline Srilanka & - Amanah Takâful & Kuwait & International Co. For Co- \\
\hline
\end{tabular}

${ }^{14}$ Salahuddin Ahmed, Islamic Banking, Finance, and Insurance, h. 541-542.

${ }^{15}$ Sumber diolah dari makalah presentasi M. Syakir Sula dan pelbagai sumber. 


\begin{tabular}{|c|c|c|c|}
\hline \multicolumn{3}{|c|}{ (1999) } & \multirow{2}{*}{$\begin{array}{l}\text { op. Insce. } \\
\text { Qatar Islamic Insce Co. } \\
\text { (1984) }\end{array}$} \\
\hline Bangladesh & $\begin{array}{ll}\text { - } & \text { Far East Islami Life } \\
& \text { Insurance (1999) } \\
\text { - } & \text { Islami Life } \\
& \text { Insurance (1999) } \\
\text { - } & \text { Islami Commercial } \\
& \text { Insurance (2000) } \\
\text { - } & \text { Islami Takâful } \\
& (2001) \\
\text { - } & \text { Prime Islami Life } \\
& \text { Insurance (2002) } \\
\end{array}$ & Qatar & \\
\hline Brunai & $\begin{array}{l}\text { - Takâful IBB (1993) } \\
\text { - Takâful TAIB (1993) } \\
\text { - Takâful IDBB (2001) }\end{array}$ & Sudan & $\begin{array}{l}\text { Al-Baraka Insce Co. } \\
\text { (1984) } \\
\text { Islamic Insce.Co. (1979) } \\
\text { Sheikan Insce. Co } \\
\text { The Nat. Re-ins. Co } \\
\text { United Insce Co. (1968) }\end{array}$ \\
\hline Singapore & $\begin{array}{l}\text { - Syarikat Takâful } \\
\text { singapore (1995) }\end{array}$ & Tunisia & Best Re (1985) \\
\hline $\begin{array}{l}\text { Eropa dan } \\
\text { lainnya }\end{array}$ & $\begin{array}{l}\text { - Australia Takâful } \\
\text { Insce Co (Australia) } \\
\text { - Islamic Takâful and } \\
\text { Retakâful } \\
\text { (Bahamas) } \\
\text { - } \text { Metropolitan Insxce } \\
\text { Co.Ltd (Ghana) } \\
\text { - International } \\
\text { Takâful Co } \\
\text { - Luxembourg) } \\
\text { - Takâful S.A (1982) } \\
\text { (Luxembourg) } \\
\text { - Sosar Al-Amane } \\
\text { (Senegal) } \\
\text { - Takâful Trinidad \& } \\
\text { Tobago } \\
\text { - Takâful UK (1982) } \\
\text { - UBK IIBU Manzil } \\
\text { programes (UK) } \\
\text { - } 1998) \\
\text { - Failaka Investment } \\
\text { Inc (USA) } \\
\text { - Takâful USA } \\
\text { Management } \\
\text { Services (USA) }\end{array}$ & $\begin{array}{l}\text { Uni Emirat Arab/ } \\
\text { Saudi Arabia }\end{array}$ & $\begin{array}{l}\text { - Alliance Insce } \\
\text { - Oman Insce } \\
\text { - Islamic Arab Insce } \\
\text { Co. } \\
\text { - } \text { Global Islamic Insce } \\
\text { - Al-Aman Coop. Insce } \\
\text { (1995) } \\
\text { - Islamic Insce Co. } \\
\text { (2002) } \\
\text { - International Islamic } \\
\text { Insce Co } \\
\text { - Islamic Arab } \\
\text { Insurance (Dallah } \\
\text { Baraka Group) (1979) } \\
\text { - Islamic Insce and } \\
\text { Reins. Co (1985) } \\
\text { - Islamic Insce and } \\
\text { Reins. Co. (1985) } \\
\text { - Islamic Corp. For isce } \\
\text { of investment \& } \\
\text { export credit (1995) } \\
\text { - Islamic International } \\
\text { Insce. Co (Salamat) } \\
\text { - Islamic Takâful and } \\
\text { Retakâful Co. (1986) } \\
\text { - Bank Al-Jazira } \\
\text { (Takâful Div) (2001) } \\
\text { - Islamic Universal } \\
\text { Insce } \\
\end{array}$ \\
\hline
\end{tabular}


- National Coop Insce Co. (NCCI) (1986)

- Takâful Islamic Insce Co.

\section{Perkembangan di Indonesia}

Perkembangan industri asuransi syariah juga terjadi di Indonesia. Pertumbuhan asuransi syariah didukung oleh ketentuan regulasi yang menjamin kepastian hukum kegiatan asuransi syariah. Ketentuan hukum yang mengatur asuransi syariah antara lain: Pertama, Undang-Undang No. 2 Tahun 1992 tentang Usaha Perasuransian. Kedua, Peraturan Pemerintah No. 73 Tahun 1992 tentang Penyelenggaraan Usaha Perasuransian, sebagaimana telah diubah dengan Peraturan Pemerintah No. 63 Tahun 1992. Ketiga, Keputusan Menteri Keuangan Nomor: 421/KMK.06/2003 tanggal 30 September 2003 tentang Penilaian Kemampuan dan Kepatutan bagi Direksi dan Komisaris Perusahaan Perasuransian. Keempat, Keputusan Menteri Keuangan Nomor: 422/KMK.06/2003 tanggal 30 September 2003 tentang Penyelenggaraan Usaha Perusahaan Asuransi dan Perusahaan Reasuransi. Kelima, Keputusan Menteri Keuangan Nomor: 423/KMK.06/2003 tanggal 30 September 2003 tentang Pemeriksaan Perusahaan Perasuransian. Keenam, Keputusan Menteri Keuangan Nomor: 424/KMK.06/2003 tanggal 30 September 2003 tentang Kesehatan Keuangan Perusahaan Asuransi dan Perusahaan Reasuransi. Ketujuh, Keputusan Menteri Keuangan Nomor: 426/KMK.06/ 2003 tanggal 30 September 2003 tentang Perizinan Usaha Perusahaan Asuransi dan Perusahaan Reasuransi.

Modus operandi pendirian asuransi syariah di Indonesia dilakukan melalui empat bentuk. Pertama, pendirian baru. Kedua, konversi dari perusahaan asuransi atau perusahaan reasuransi konvensional. Ketiga, pendirian kantor cabang baru dengan prinsip syariah oleh perusahaan asuransi atau perusahaan reasuransi konvensional. Keempat, konversi kantor cabang konvensional menjadi kantor cabang dengan prinsip syariah dari perusahaan asuransi atau perusahaan reasuransi konvensional. ${ }^{16}$

Untuk pendirian baru tidak terlalu banyak masalah yang dihadapi terutama terkait dengan nasabah. Sedangkan untuk konversi ada ketentuan yang harus dipenuhi menyangkut kesediaan pemegang polis. Berikut adalah ketentuan khusus konversi. Pertama, tidak merugikan tertanggung atau pemegang polis. Kedua, memberitahukan konversi tersebut kepada setiap pemegang polis. Ketiga, memindahkan portfolio pertanggungan ke perusahaan asuransi konven-

\footnotetext{
${ }^{16}$ Pasal 3 KMK Nomor 426/KMK.06/2003.
} 
sional lain atau membayarkan nilai tunai pertanggungan, bagi tertanggung atau pemegang polis yang tidak bersedia menjadi tertanggung atau pemegang polis dari perusahaan asuransi dengan prinsip syariah. ${ }^{17}$

Baik pendirian baru maupun konversi, suatu perusahaan asuransi syariah dapat beroperasi apabila mendapat izin usaha dari Kementerian Keuangan. Izin usaha itu diberikan setelah pengajuan pendirian atau konversi memenuhi syaratsyarat sebagai berikut: Pertama, maksud dan tujuan di dalam anggaran dasar perusahaan. Kedua, memiliki tenaga ahli. Ketiga, memiliki Dewan Pengawas Syariah (DPS) perusahaan. Keempat, memenuhi minimal modal disetor atau minimal modal kerja (bagi pendirian cabang). Kelima, tingkat solvabilitas (bagi pendirian cabang). Keenam, tidak sedang dalam pengenaan sanksi administratif (bagi pendirian cabang). Ketujuh, persyaratan-persyaratan lainnya, sebagaimana halnya persyaratan dalam pembukaan kantor cabang konvensional. ${ }^{18}$

Untuk mendukung perkembangan asuransi syariah di Indonesia, DSN pada tahun 2001 mengeluarkan fatwa No.21/DSN-MUI/X/2001 tentang Pedoman Umum Asuransi Syariah, yang menjadi acuan dari sisi syariah dalam penyelenggaraan kegiatan asuransi syariah di Indonesia.

Perkembangan industri asuransi syariah di Indonesia dapat dilihat pada tabel (data tahun 2000-Juli 2007) berikut ${ }^{19}$ :

\begin{tabular}{|c|c|c|c|c|c|c|c|}
\hline No. & Keterangan & 2002 & 2003 & 2004 & 2005 & 2006 & Juli 2007 \\
\hline 1. & $\begin{array}{l}\text { Perusahaan Asuransi Jiwa } \\
\text { Syariah }\end{array}$ & 2 & 2 & 2 & 2 & 2 & 2 \\
\hline 2. & $\begin{array}{l}\text { Perusahaan Asuransi Kerugian } \\
\text { Syariah }\end{array}$ & 1 & 1 & 1 & 1 & 1 & 1 \\
\hline 3. & $\begin{array}{l}\text { Perusahaan Asuransi Jiwa yang } \\
\text { memiliki Kantor Cabang } \\
\text { Syariah }\end{array}$ & 1 & 2 & 3 & 8 & 9 & 12 \\
\hline 4. & $\begin{array}{l}\text { Perusahaan Asuransi Kerugian } \\
\text { yang memiliki Kantor Cabang } \\
\text { Syariah }\end{array}$ & 1 & 6 & 11 & 13 & 15 & 18 \\
\hline 5. & $\begin{array}{l}\text { Perusahaan Reasuransi yang } \\
\text { memiliki Kantor Cabang } \\
\text { Syariah }\end{array}$ & - & - & 1 & 2 & 3 & 3 \\
\hline & TOTAL & 5 & 11 & 18 & 26 & 30 & 36 \\
\hline
\end{tabular}

\footnotetext{
${ }^{17}$ Pasal 4 KMK Nomor 426/KMK.06/2003.

${ }^{18}$ Pasal 4,31,32 dan 33 KMK Nomor 426/KMK.06/2003.

${ }^{19}$ Sumber: Bapepam \& LK, Biro Asuransi.
} 
Berikut adalah data perusahaan asuransi syariah yang ada di Indonesia, baik yang bersifat asuransi umum atau unit usaha syariah dari asuransi konvensional.

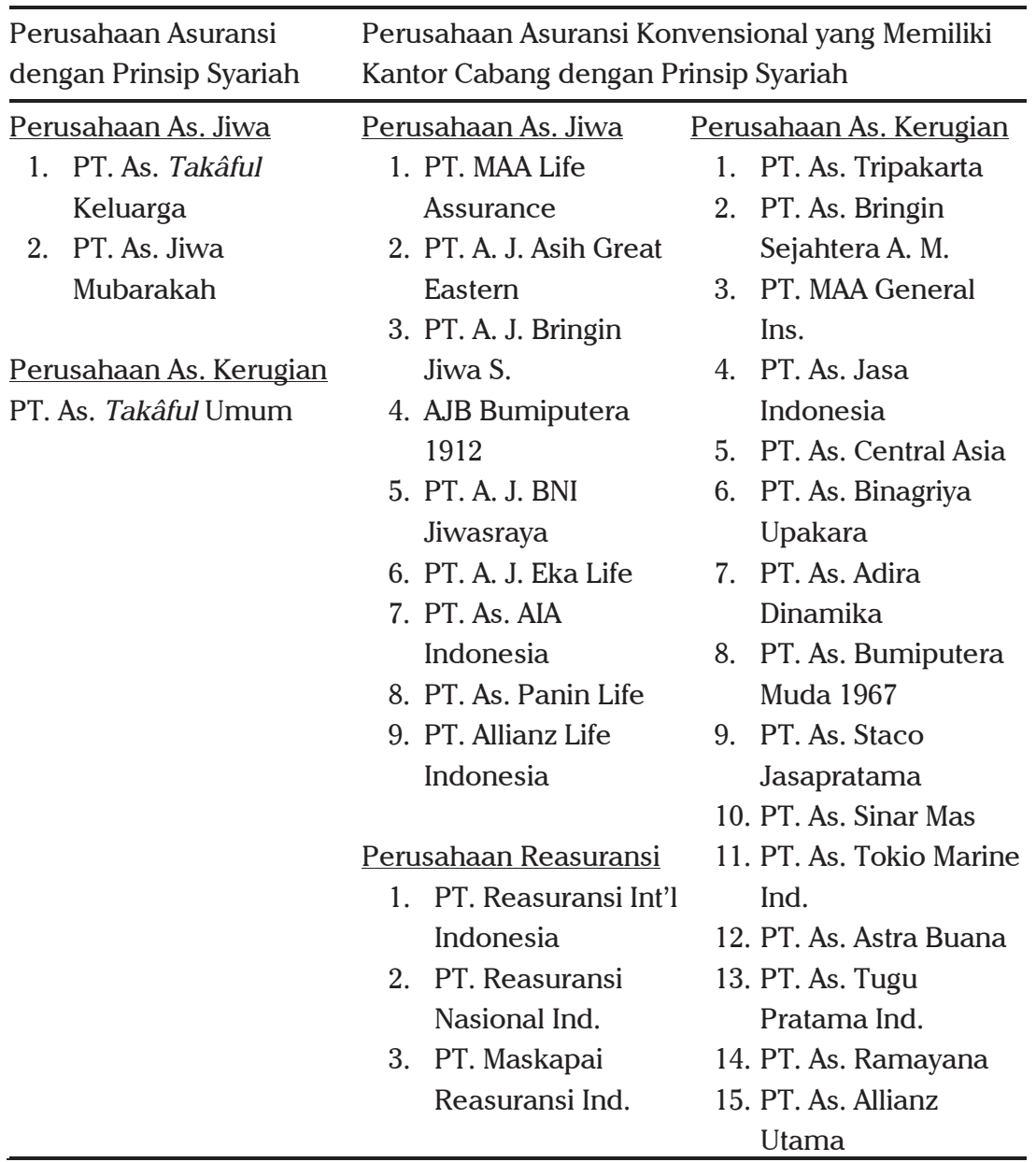

Dari sisi kuantitas, jumlah perusahaan asuransi syariah terbilang banyak, namun dilihat dari perbandingannya dengan asuransi konvensional (market share), tergolong masing rendah. Tahun 2006, perbandingan aset asuransi syariah hanya $0,87 \%$ dari asuransi konvensional untuk jenis asuransi jiwa. Sedangkan untuk asuransi kerugian dan reasuransi hanya $1,41 \%$. Jumlah ini jelas tidak sebanding dengan jumlah umat Islam yang mayoritas di Indonesia. 


\section{Kesyariahan Asuransi Takâful}

Yang membedakan asuransi syariah dengan asuransi konvensional adalah keterkaitannya dengan hukum agama. Ketentuan-ketentuan yang membedakan itu, sebagaimana dijelaskan di atas, antara lain sistem tolong-menolong, menghindarkan praktik riba, maysir, gharar, dan jahâlah, zhulm, dan kegiatan maksiat lainny/a.

Salah satu yang menjadi bagian penting dari asuransi syariah adalah akad (kontrak) yang membangunnya. Akad dalam asuransi syariah terdiri dari akad, yaitu akad mu'âwadhah dan tabarru'. Akad mu'âwadhah digunakan antara nasabah dan perusahaan dimana dengan sistem mudhârabah, perusahaan berfungsi sebagai mudhârib dan nasabah sebagai shâhib al-mâl. Sedangkan akad tabarru' terjadi antar para nasabah. Berikut ketentuan akad yang dijelaskan dalam fatwa DSN. Pertama, akad yang dilakukan antara peserta dengan perusahaan terdiri atas akad tijârah dan/atau akad tabarru'. Kedua, akad tijârah yang dimaksud dalam ayat (1) adalah mudhârabah. Sedangkan akad tabarru' adalah hibah. Ketiga, dalam akad, sekurang-kurangnya harus disebutkan: (a) Hak \& kewajiban peserta dan perusahaan; (b) Cara dan waktu pembayaran premi; (c) Jenis akad tijarah dan/atau akad tabarru' serta syarat-syarat yang disepakati, sesuai dengan jenis asuransi yang diakadkan.

\section{Penutup}

Meski asuransi syariah telah berkembang pesat di negeri ini, namun masih banyak kendala yang dihadapi, terutama terkait dengan regulasi dan pengetahuan sumber daya manusia akan sistem syariah. Saat ini, regulasi yang digunakan untuk kegiatan asuransi syariah hanya sebatas peraturan menteri keuangan, itupun tidak ada aturan yang khusus mengatur kegiatan asuransi syariah. Belum lagi pengetahuan pihak regulator akan prinsip-prinsip syariah dalam asuransi syariah. Termasuk para pelaku asuransi syariah masih banyak yang belum memahami ketentuan-ketentuan syariah. Tidak luput pula, para anggota Dewan Pengawas Syariah (DPS). []

\section{Pustaka Acuan}

Ba'ly', al-, Abd al-Hamîd Mahmûd, Mafâhîm Asâsiyyah fî al-Bunûk al-Islâmiyyah, al-Qâhirah: Al-Ma'had al-'Âlamî Li al-Fikri al-Islâmî, 1996.

Dasûkî, al-, Muhammad Sayyid, al-Ta'mîn wa Mauqif al-Syarîah al-Islâmiyyah Minhu, al-Qâhirah: Direktorat Tinggi Urusan Agama Mesir, 1967.

DSN-MUI dan Bank Indonesia, Himpunan Fatwa Dewan Syariah Nasional MUI, Edisi Revisi 2006 Jakarta: DSN-MUI, 2006.

Keputusan Menteri Keuangan Nomor 426/KMK.06/2003. 
Edisi Revisi 2006 Jakarta: DSN-MUI, 2006.

Keputusan Menteri Keuangan Nomor 426/KMK.06/2003.

Manzhûr, Abu al-Fadhl Jamâl al-Dîn Muhammad ibn Makram Ibn, Lisân al-'Arab, Lubnân: Dâr Shâdir Beirut, t.th.

Milhim, Ahmad Sâlim, al-Ta'mîn al-Islâmy, Oman: Dâr al-A'lâm, 2002.

Oxford Learner's Pocket Dictionary, New Edition.

Qal'ahaji, Muhammad Rawwâs, al-Mu'âmalât al-Mâliyyah al-Mu'âshirah fi Dhau al-Fiqh wa al-Syarî'ah, Bayrût: Dâr al-Nafâs, 1999.

Sula, Syakir, Ansuransi Syariah, Konsep dan Sistem Operasional, Jakarta, Gema Insani, 2004.

Undang-Undang Republik Indonesia Nomor 2 Tahun 1992 Tentang Usaha Perasuransian. 